\title{
The Main Drivers of Competitiveness in the EU-28 Countries
}

\author{
- Mihaela Simionescu, Elena Pelinescu, Samer Khouri, Svitlana Bilan
}

\begin{abstract}
During the past few decades, globalization has dramatically changed the context of competitiveness around the world. Considering the role of competitiveness in the development of the digital economy, this paper aims to highlight the role of innovation, foreign direct investment (FDI), and human capital in supporting competitive European economies. The research hypothesis is that FDI, innovation, and human capital contribute to competitiveness growth. The paper extends the Cobb-Douglas function by including other competitiveness factors in a panel data framework based on the EU-28 countries in the period 2004-2018. The results indicate that GDP per capita variation is explained by human and physical capital, FDI, and R\&D expenditure. Human capital plays a crucial role in economic development due to the innovation skills of individuals, which improve the productivity of these factors. Capital formation also makes a positive contribution to economic growth. The empirical evidence suggests that the changes in the GDP per capita are explained by modifications in the labor force and capital formation, as is described in the traditional framework of the Cobb-Douglas function. R\&D expenditure and FDI stock, however, also play a significant role. Moreover, human capital could determine the adoption of external technology by absorbing new equipment and ideas. On the other hand, the education index and capital formation showed a positive impact on GCI.
\end{abstract}

Keywords: competitiveness, human capital, innovation, FDI, panel data model

JEL Classification: E24, F02, F21, O15, O31, J24, J33

Received: July, 2020

1st Revision: January, 2021

Accepted: February, 2021

\section{INTRODUCTION}

During the last few decades, globalization and the acceleration of digitization adoption as the result of the Covid-19 crisis have changed the context of competitiveness around the world dramatically. There is an interconnected world where globalization has accelerated technological transfers. As a result of the third industrial revolution, digitization has facilitated access to both local and international markets, with significant impacts on competitiveness (Szeles \& Simionescu, 2020).

In numerous studies, many factors have been shown to have significant effects on competitiveness, most of this work has been incorporated into the Global Competitive Index aggregate, which 
is based on 12 pillars (institutions, infrastructure, ITC adoption, macroeconomic stability, health, skills, product market, labor market, financial system, market size, business dynamism, and innovation capabilities) and is measured through 103 individual indicators. The results for 2019 reveal that the "GCI score across the 141 economies studies is 60.7, meaning that the distance to the frontier stands at almost 40 points" (Schwab, 2019). Competitiveness registered a "declining trend in fundamental aspects of productivity," reclaiming in the digitization era a "transformation toward new economic systems" that will combine "productivity, people and planet targets" (Schwab \& Zahidi, 2020) as essential factors for improving the competitiveness in the future (Gavurova et al., 2020). In the digitization era, productivity is linked with the process of diffusion of innovation and technologies, with infrastructure (inclusive ITC infrastructure), equipment, and new technologies as essential elements. Innovation, considered as linking new ideas to the market or "a process of universal essence that has to be viewed from a systemic perspective" (Manuylenko et al., 2015) is also an important factor of increasing competitiveness (Priede \& Pereira, 2013). Foreign direct investment (FDI) stimulates competition through the spillover of new technologies, long-life learning processes, and new managerial practices based on digitization, the effects of which on competitiveness depend on human capital in host countries in the form of education and skills. Human capital as a complementary and endogenous growth factor will require new skills, higher investment into education, as well as updated education curricula and reskilling programs to answer the latest labor market demand (Suroso et al., 2020). In this context Prívara (2020) emphasizes the importance of market conditions and emigration trends in the EU.

In Europe, the enlargement process of the EU led to significant heterogeneity, which affected development and competitiveness under the EU policy and created high discrepancies. The EU has upgraded its competitiveness to meet the new challenges using the meaningful opportunities created by one of the world's largest markets as an efficient platform for organizing joint venture action, i.e. a place for improving local practices among members and providing technical support and co-financing. The single market of the European Union has served to increase competition between countries with significant differences, especially between older members and the newly integrated Eastern European countries, who have greatly affected by the transition. All of the changes involved could impact competitiveness directly or indirectly.

In this context, the paper focuses on Europe after the enlargement, when the disparities among countries increased based on differences between previously and newly entering countries. The research hypothesis is that FDI, innovation, and human capital contribute to competitiveness growth. The study aims to highlight through appropriate models the relationship between FDIhuman capital and innovation in the countries of the European Union and competitiveness. GCI and GDP per capita at PPP are used as metrics of competitiveness. As FDI, innovation, and human capital might affect national competitiveness, the paper checks if these factors influenced competitiveness at EU level in the period 2004-2018, after the European enlargement.

Firstly, the novelty of paper derives from the fact that authors model the influence of the chosen three factors on two alternative indicators selected as a proxy for competitiveness: the first being the composite indicator GCI, as "macroeconomic indicators do not reflect the real reality" (Baltgailis, 2019). The second indicator is gross domestic product (GDP) per capita, usually 
considered to be a good measure of the welfare of a country. A long-term objective of the EU has been set to increase competitiveness to offer their population a high standard of living. The correlation coefficient between these two indicators for the EU 28 countries for 2006-2016 was 0.58 (Dobrovic et al., 2018), a significant statistical level to be used as a proxy for competitiveness. Secondly, the novelty of this paper derives from the fact that authors applied a mixed econometric method: i) the regression method, using the MG estimator for each panel member (Pesaran \& Smith, 1995) and CCEMG estimator (Pesaran, 2006); ii) dynamic panel regression models and a ridge regression estimated in a Bayesian framework to determine the most competitive countries in the EU. Based on the indicators chosen as a measure for competitiveness and econometric methods, the results identify significant differences. The paper is organized into three parts: a synthetic view of literature, a short presentation of the methodology, and an empirical analysis with comments on the results and conclusions.

\section{LITERATURE REVIEW}

A bibliometric study of economics literature over the last 70 years has investigated international competitiveness. Since 1970 authors have been focused on this topic, with their results published in 457 journals, which reveals the importance of this topic (Olczyk, 2016). The study shows that the papers could be grouped into four clusters based on the role of different factors seeking to explain international competitiveness. The first cluster is related to the role of knowledge, human capital, and innovation. The second is associated with the level of technological development, the third is related to location and globalization, and the last cluster is linked to environmental policy and regulation changes. Many approaches to competitiveness based on different competitiveness metrics have been employed, such as standard price indicators (Altomonte \& Békés, 2014); nonprice competitiveness factors that might explain $30-40 \%$ of the export variation among EU countries, with the rest explained by standard export equation (Christodoulopoulou \& Tkacevs, 2014); computed indicators such as GCI; and wealth creation and productivity as the primary driver of cross-country differences (Squalli et al., 2008).

In a number of papers, competitiveness is shown as productivity, with some authors demonstrating the vital role of R\&D and innovation in terms of increased productivity as a measure of competitiveness (e.g. Fernando, 2020). Giménez et al., (2015) applied alternative measures for human capital, concluding that no positive relationship exists between human capital and economic growth when human capital is measured by the average number of years of schooling in the total population or enrolment rate in secondary education. This relationship was strong in the 15 OECD countries in the period 1980-2005 if the new indicator proposed by the authors is taken into account. Regarding the relationship with innovation, the Granger causality test indicated a strong link between the new human capital indicator and the number of patents granted. The results are in line with the new theory of endogenous growth. An analysis of the growth of human capital as a source to increase the number of innovative entrepreneurs and innovative products that indirectly drive economic growth through the innovative channel demonstrate, based on an OLS regression model, the existence of a long-term relationship between human capital, innovation and economic growth from a regional perspective, using the 265 NUTS 2 or equivalent regions of the European Union (Diebolt \& Hippe, 2019). 
Another study is convinced about the idea that if the competitiveness in the EU should be understood, the focus must look at drivers of performance of top companies like the quality of human capital, institutional framework conditions, access to market, quality and branding, and ability of the firm to use the global value production chains (Wolff, 2016). The relationship between global competitiveness based on GCI and economic growth rate for 114 countries covering the period 2006-2014 showed the following when a panel Granger causality was used: a unidirectional causality from GDP growth to GCI, the fact that GCI can predict development only in a particular case, the relation was valid only in $66 \%$ of the total case samples, most often in the low-income countries (14 out of 15 that were investigated) and rarely in the case of middleincome countries. (Kordalska \& Olczyc, 2016).

Some papers focus on Competitiveness in EU countries based on GCI indicators and correlation with sub-index (Marčeta \& Bojnec, 2020; Mura, 2020; Ivanová \& Masárová, 2018; Zoroja \& Pejić Bach, 2016) that show the importance of financial effort to sustained: i) research and innovation process at the national level to offer more products to internal and external market; ii) education system to increase the national human capital; iii) ITC infrastructure; iv) financial market development, etc.

In the last 8 years, the competitiveness gap of EU countries in the context of Europe 2020 Strategy shows, using the Global Competitive Index, that EU 10 (Austria, Belgium, Denmark, Finland, France, Germany, Luxemburg, the Netherlands, Sweden and the United Kingdom) are closer to the US, and that China and India registered very rapid growth and improvement of the GCI score. Based on Innovation criteria, Finland, Germany, Sweden, the Netherlands, Denmark, and UK are the most innovative countries of EU. Three of them (Finland, Sweden and Denmark) fulfill the 3\% target and Germany with $2.84 \%$ is very close, but under the $4 \%$ target in South Korea, 3.4\% in Japan and less than 3\% in the US (Priede \& Neuert, 2015).

An analysis of the relationship between the three sub-index of competitiveness and GCI on the one hand, and between research in industries and university and cluster development on competitiveness in the EU 28 countries on the other, highlight: i) the existences of a positive correlation between GCI and GDP per capita (0.67), and a not significant level for indicators of tertiary education (0.43); ii) that the level of the correlation between GDP per capita and enrolment into tertiary education was only 0.07 ; iii) the highest correlation coefficient for GCI with technology (absorption capacity- 0.94 and availability-0.93) and quality of the educational system (0.84), that means that innovation and education of labor force are essential drivers for competitiveness in EU 28 (Marčeta \& Bojnec, 2020).

The analyses of the impact of innovation on productivity and growth in EU-28 from 1995 to 2013 show that: i) the correlation coefficient was positive and significant (over the 0.5) in 16 EU member states; ii) the coefficients were negative in five countries (France, the Netherlands, Slovakia, Sweden and UK), but only in one case, it was statistically significant at $5 \%$ and the correlation was weak (UK); for the rest of the countries, the level was positive but under 0.5 and statistically insignificant at $5 \%$; iii) a level of $2.85 \%$ of GDP investment in R\&D maximized labor productivity, even if it is under $3 \%$, it is considered to be the target for 2020, taking into consideration that; in 2018 the average level for EU 28 was 2.12, and only four countries registered a level over 3\% (Austria, Denmark, Germany, and Sweden) (Nekrep et al., 2018). 
A study that analyzed the driver role of information and communication technology (ITC) to the competitiveness of European countries in 2011, using the K-means method to choose the four clusters and ANOVA analysis to test differences between them. The results show that Western, Northern, and Central Europe provide the most competitive countries in the world and invest more in ITC as compared to the countries that have recently entered UE that registered a development lag as compared to the countries from the first two clusters (Zoroja \& Pejić Bach, 2016). The role of innovation in economic growth appeared in a wide range of papers, but Florida (2002) highlighted the link between knowledge and economic development by introducing creative classes to measure human capital, which has creative capabilities.

The analyses of the impact of patent innovation and R\&D on economic growth in the old EU member states (15 countries) and the new ones (13 countries) between 1993-2011 show that the knowledge pool reduces the cost of R\&D for future innovations and the knowledge created as a result of R\&D helps to increase the effectiveness of physical and human capital. Moreover, using panel models, the authors did not reveal any significant statistical link between R\&D expenditure and economic growth in EU15 and EU13 countries. In contrast, patent-related growth results were significant, positive in EU-13 countries, and insignificant in the EU15 (Kacprzyk \& Doryń, 2017).

A study about the driver of competitiveness in the New EU Member State show, based on the dynamic panel model on one-step GMM estimator during 1999-2016, that the government and structure of export goods have a positive role in competitiveness measured as GDP per person employed. So, it can be stated that the competitiveness of contemporary economies is determined by non-price factors as governance indicators, financial development and efficiency of market services (Dumančić \& Mačkić, 2017).

In terms of FDI, studies on their impact on economic growth are numerous, some of them pointing out that the effect of FDI on labor productivity, and hence on economic growth, depends on the absorption capacity of host countries. The interactions between the educated and high-educated population, being more mobile, could provide knowledge transfer, which means that human capital, measured by the educational level reached, and the intensity of small and medium-sized firms are statistically associated with development. Simultaneously, classes of creative workers or the share of advanced technology industries are insignificant from this perspective in the US (Faggian et al., 2016).

All these papers highlight, based on different models proving that human capital, FDI, and innovation are important factors with direct effects on competitiveness at the national or regional level, but many other factors contribute to competitiveness development at the national or regional level. Also, the papers highlight that the competitiveness could be measured by composed indices as GCI or other indicators as a proxy for productivity or economic growth.

\section{RESEARCH OBJECTIVE, METHODOLOGY AND DATA}

This research aims to explain two indicators that reflect the economic competitiveness in the EU-28 in the period 2004-2018: GDP per capita growth and global competitiveness index. The research hypothesis is that FDI, innovation and human capital contribute to competitiveness 
growth. Given this hypothesis, a Cobb-Douglas production function was extended to include different perspectives of technological progress.

Let's start from the standard form of the Cobb-Douglas production function:

$\mathrm{Y}_{\mathrm{t}}=\mathrm{A}_{\mathrm{t}} \cdot \mathrm{K}_{\mathrm{t}}^{\alpha} \cdot \mathrm{L}_{\mathrm{t}}^{1-\alpha}$

where Y- output at time t, K- capital stock at time t, L-labor force at time t, $\alpha$-parameter $(0<\alpha<1)$, A-parameter including total factor productivity which primary components are efficiency and technological progress.

It can be assumed that technology is determined by aspects related to skilled human capital (personnel and expenses in the $\mathrm{R} \& \mathrm{D}$ sector, population with tertiary education, innovation index, human development index), and investment (FDI stock and inflows). Suitable proxies for output growth might be represented by GDP per capita growth and global competitiveness index. In this context, it can be assumed a technology model:

$\mathrm{A}_{\mathrm{t}}=\mu \cdot \mathrm{SHC}_{\mathrm{t}}^{\beta} \cdot \mathrm{I}_{\mathrm{t}}{ }^{\gamma}$

$\mu, \beta, \gamma$ - parameters, $\mathrm{SHC}_{\mathrm{t}}$ - skilled human capital at time $\mathrm{t}, \mathrm{I}_{\mathrm{t}}$ - investment at time $\mathrm{t}$ (foreign direct investment), u- error term (white noise)

If the value of $A_{t}$ in equation (1) is replaced and the corresponding regression model is written, the results will be:

$\mathrm{Y}_{\mathrm{t}}=\mu \cdot \mathrm{SHC}_{\mathrm{t}}^{\beta} \cdot \mathrm{I}_{\mathrm{t}} \cdot \mathrm{K}_{\mathrm{t}}^{\alpha} \cdot \mathrm{L}_{\mathrm{t}}^{1-\alpha \cdot u}$

The log-linearized form of the model is considered for estimations:

$\ln \mathrm{Y}_{\mathrm{t}}=\mu+\beta \cdot \mathrm{SHC}_{\mathrm{t}}+\gamma \cdot \mathrm{I}_{\mathrm{t}}+\alpha \cdot \mathrm{K}_{\mathrm{t}}+(1-\alpha) \cdot \mathrm{L}_{\mathrm{t}}+\mathrm{u}_{\mathrm{t}}$

In the case of more countries (all the EU countries, including the UK; i-index for the country) for which the data are registered in a certain period (2004-2018), the panel data model can be considered as follows:

$\ln \mathrm{Y}_{\mathrm{it}}=\mu+\beta \cdot \mathrm{SHC}_{\mathrm{it}}+\gamma \cdot \mathrm{I}_{\mathrm{t}}+\alpha \cdot \mathrm{K}_{\mathrm{it}}+(1-\alpha) \cdot \mathrm{L}_{\mathrm{it}}+\mathrm{u}_{\mathrm{it}}$

Before constructing the panel data models, the stationary data is checked using unit root tests for data in level and for logarithmic data. As authors have unbalanced panel data, the Im-PesaranShin test is applied to check for stationarity. The logarithm data are stationary in the first level for all variables at a 10\% level of significance. Therefore, authors will focus on heterogeneous panel estimators: all mean group type estimator (MG) and common correlated effects mean group estimator (CCEMG). Authors start from the following model:

$\mathrm{Y}_{\mathrm{it}}=\beta_{\mathrm{i}} \mathrm{X}_{\mathrm{it}}+\mathrm{u}_{\mathrm{it}}$

$\mathrm{X}_{\mathrm{it}}=\alpha_{1 \mathrm{i}}+\tau_{\mathrm{i}} \cdot \mathrm{f}_{\mathrm{t}}+\gamma_{\mathrm{i}} \cdot \mathrm{g}_{\mathrm{t}}+\mathrm{e}_{\mathrm{it}}$

$\mathrm{u}_{\mathrm{it}}=\alpha_{2 \mathrm{i}}+\tau_{\mathrm{i}} \cdot \mathrm{f}_{\mathrm{t}}+\varepsilon_{\mathrm{it}}$

$i=1,2, \ldots, N$ and $T=1,2, \ldots, T, \beta_{i}$ - country-specific slope associated with explanatory variables, $f_{t}$, $\mathrm{g}_{\mathrm{t}^{-}}$unobserved common factor, $\tau_{\mathrm{i}}$ - factor loadings capturing heterogeneity that does not change in time and cross-section dependence, $\varepsilon_{\mathrm{it}}, \mathrm{e}_{\mathrm{it}}-$ white noise. The variables $\mathrm{X}_{\mathrm{it}}$ and $\mathrm{Y}_{\mathrm{it}}$ are observable. 
$\mathrm{u}_{\mathrm{it}}$ includes errors $\left(\varepsilon_{\mathrm{it}}\right)$ and unobservable factors. $\alpha_{1 \mathrm{i}}$ and $\alpha_{2 \mathrm{i}}$ capture heterogeneity across groups that does not change in time.

The MG estimator calculation supposes the estimation of $\mathrm{N}$ group-specific OLS regressions and the computation of average based on estimates across groups. MG estimator does not assume cross-section dependence, and it is built for each panel member (Pesaran \& Smith, 1995). CCEMG estimator allows for cross-section dependence and time-variant unobservable with heterogeneous effect across countries (Pesaran, 2006). The cointegration between variables is checked using the Westerlund test under two assumptions: some panels are cointegrated and all panels are cointegrated (Westerlund and Edgerton, 2007). Granger causality in the panel is also reviewed for stationary data. Dynamic panel regression models will be run to assess the impact of different variables on GDP per capita and GCI. Preliminary tests confirmed the existence of endogeneity. In the following equation (9), GDP per capita, respectively GCI is explained based on a set of endogenous variables.

$\mathrm{y}_{\mathrm{it}}=\alpha \mathrm{y}_{\mathrm{i}, \mathrm{t}-1}+\beta \mathrm{X}_{\mathrm{it}}+\varepsilon_{\mathrm{it}}$

$\varepsilon_{\mathrm{it}}=\mathrm{u}_{\mathrm{i}}+\mathrm{v}_{\mathrm{it}}$

$\mathrm{X}_{\mathrm{it}}{ }^{-}$a vector of exogenous regressors, $\alpha, \beta$-column vectors of coefficients, $\mathrm{y}_{\mathrm{it}}$ and $\varepsilon_{\mathrm{it}}-$ random variables. Error term sit has two orthogonal components: ui (fixed effects), and vit (idiosyncratic shocks).

The differences between countries in terms of competitiveness make us consider a separate analysis for the sample countries with the highest GCI. Specific methods are deemed to process short time series for these countries. Therefore, ridge regression estimated in a Bayesian framework is considered for most competitive countries in the EU. Ridge regressions were built to GCI in these countries. Authors started the empirical analysis with information about the data used in the model. As authors explain the economic performance based on different factors, starting from the Cobb-Douglas function, more potential explanatory variables are considered in the analysis:

- gross capital formation as a percent of GDP that will be used in the analysis as the increase in the stock of physical capital stock is expected to have a positive impact on production;

- number of employed people in thousand persons from 15 to 64 years that will be considered as labor force;

- population with tertiary education as percent in total population from 15-64 years, and Education Index (EDI), calculated using mean years of schooling and expected years of education, was used as a proxy for human capital. Higher education is one of the crucial sources for the high skilled labor force that could support export growth and competitiveness (Landesmann \& Leitner, 2015). Authors used the indicators that describe people's education considering that the educated labor force is better at adopting new technologies. Technological progress could be modeled as a function of the level of education or human capital. The growth models based on the standard Cobb-Douglas production function show that human capital growth has insignificant effects in explaining per capita income growth. 
- variables that reflect aspects from the R\&D sector: Intramural R\&D expenditure (GERD) in euro per capita, and R\&D personnel expressed as full time; higher R\&D and innovation will generate higher competitiveness;

- indicators that reflect technological progress: Innovation Index also used by Atkinson (2013) that explain the role of innovation in enhancing competitiveness;

- FDI as FDI inflow and FDI stock, from FDI/MNE database (www.unctad.org/fdistatistics); UNCTAD, United Nations. According to economic theory, FDI should enhance economic growth, which improves competitiveness.

The variables, their computation and sources of data are presented in Table 1.

Tab. $1 \neg-$ Model variables. Source: own research

\begin{tabular}{|c|c|c|}
\hline $\begin{array}{l}\text { Variable used in the } \\
\text { models }\end{array}$ & Computation & Source of data \\
\hline $\begin{array}{l}\text { Gross capital } \\
\text { formation }\end{array}$ & As a percent of GDP $(\%)$ & \multirow{5}{*}{ Eurostat } \\
\hline $\begin{array}{l}\text { Number of employed } \\
\text { people }\end{array}$ & $\begin{array}{l}\text { In thousand persons from } 15 \text { to } 64 \\
\text { years }\end{array}$ & \\
\hline $\begin{array}{l}\text { Population with } \\
\text { tertiary education }\end{array}$ & $\begin{array}{l}\text { As percentage in total population } \\
\text { from } 15-64 \text { years }(\%)\end{array}$ & \\
\hline $\begin{array}{l}\text { Expenditure in the } \\
\text { R\&D sector }\end{array}$ & $\begin{array}{l}\text { Intramural R\&D expenditure } \\
\text { (GERD) in euro per capita }\end{array}$ & \\
\hline R\&D personnel & Computed as a full time & \\
\hline $\begin{array}{l}\text { Education Index } \\
\text { (EDI) }\end{array}$ & $\begin{array}{l}\text { Calculated using mean years of } \\
\text { schooling and expected years of } \\
\text { schooling }\end{array}$ & $\begin{array}{l}\text { Human Development } \\
\text { Report, UNDP }\end{array}$ \\
\hline Innovation index & $\begin{array}{l}\text { Computed based } 27 \text { indicators } \\
\text { aggregated into four subindices: } \\
\text { framework condition, investment, } \\
\text { innovation activities, and impacts }\end{array}$ & $\begin{array}{l}\text { European Innovation } \\
\text { Scoreboard, 2010, 2017- } \\
\text { 2019, Annex F, and } 2007 \\
\text { Annex D }\end{array}$ \\
\hline $\begin{array}{l}\text { FDI inflow and FDI } \\
\text { stock }\end{array}$ & mil. Dollar & FDI/MNE database \\
\hline $\begin{array}{l}\text { Global } \\
\text { Competitiveness } \\
\text { Index GCI }\end{array}$ & $\begin{array}{l}\text { GCI is computed based on } 98 \\
\text { indicators in 2018, organized into } 12 \\
\text { pillars. }\end{array}$ & \multirow[b]{2}{*}{ World Bank } \\
\hline $\begin{array}{l}\text { GDP per capita in } \\
\text { PPP (growth rate } \\
\text { real) }\end{array}$ & $\begin{array}{l}\text { GDP per capita in PPP (growth rate } \\
\text { real) represents the annual percentage } \\
\text { growth rate of GDP per capita using } \\
\text { constant local currency. }\end{array}$ & \\
\hline
\end{tabular}

The dependent variable is represented by GDP per capita in PPP, which is considered to be a proxy for national competitiveness (Petrariu et al., 2013) and, respectively, the global competitiveness 
index (GCI). There is a moderate correlation between these two indicators (0.664), comparable with the results of Dobrovic et al. (2018), who show a correlation coefficient of 0.58.

\section{RESULTS AND DISCUSSION}

The hypotheses of cross-section dependence and heterogeneity are fulfilled since the economic growth or competitiveness in an EU country depends on the economic evolutions in other EU countries. Still, specific-country effects in the short-run made them different from other perspectives. The heterogeneity is explained by the different responses of governments to external shocks. The heterogeneous short-run and long-run relationships are reflected by the MG estimator that is consistent for many countries like in this analysis (28 countries). The main benefit of MG and CCEMG estimators is the alleviation of endogeneity (Pesaran et al., 1999).

On the other hand, the assumption of homogeneity could be fulfilled in the long term when CCEMF provides efficient and consistent estimators (Pesaran, 2006). Dynamic panel data models also reduce endogeneity. Ridge regressions for country-level analysis are justified by the small number of observations in the sample, which makes traditional linear regression unsuitable in this case. Firstly, the presence of unit roots is detected using a test for unbalanced panels, ImPesaran-Shin test. GDP per capita, expenditure in the R\&D sector, EDI, innovation index, capital formation, FDI inflows, and FDI stock are stationary at a 10\% level of significance. The rest of the variables are stationary in the first difference. The data for all variables are transformed by applying the logarithm. These variables are stationary in the first difference. CCEMG estimators are computed to explain GDP per capita, and then MG and CCEMG estimators are calculated to describe GCI in the EU-28 in Table 2 and Table 3.

Tab. 2 - Heterogenous panel estimators for explaining GDP per capita growth in the EU-28 (2004-2018). Source: own research

\begin{tabular}{|l|l|l|}
\hline Variable & \multicolumn{2}{l|}{ CCEMG estimator } \\
\cline { 2 - 3 } & Coefficient & p-value \\
& & \\
\hline $\ln ($ expenditure in the R\&D sector) & 1.310 & 0.075 \\
\hline $\ln ($ labor force) & -4.449 & 0.027 \\
\hline $\ln ($ capital formation) & 3.371 & 0.076 \\
\hline Cross-section averaged $\ln ($ GDP per capita) & 1.402 & 0.000 \\
\hline Cross-section averaged $\ln ($ expenditure in the R\&D sector) & -4.02 & 0.097 \\
\hline Cross-section averaged $\ln ($ labor force) & 5.374 & 0.020 \\
\hline Cross-section averaged $\ln ($ capital formation) & -5.150 & 0.026 \\
\hline Constant & 4.558 & 0.479 \\
\hline
\end{tabular}

According to the results in Table 2, the changes in the GDP per capita are explained by changes in the labor force and capital formation like in the traditional framework of Cobb-Douglas function, but also by R\&D expenditure and FDI stock. Capital formation has a positive contribution, 
while a decline in the labor force does not slow down GDP per capita. The logarithm variables of expenditure in the R\&D sector are significant but are an incorrect sign similar to the results of Petrariu et al. (2013), who obtained the same sign in a pooled data regression between economic growth and its determinants in the case of CEE countries and consider that this result suggests a catch-up process. Also, the logarithm of the labor force has an insignificant contribution, and the impact on GP per capita was negative, similar to the result obtained by Kosztowniak (2013). "Unequal distribution of education tends to have a negative impact on per capita income in most countries." Fathy \& Safijllin (2019) show using panel data for EU countries that "impact on labor force on real GDP per capita, have a big problem about the data on the labor market for wages and efficiency of the labor market. When the labor force participation was employed, the result was insignificant, and the sign was negative.

Tab. 3 - Heterogenous panel estimators for explaining GCI in the EU-28 (2004-2018). Source: own research

\begin{tabular}{|l|l|l|l|l|}
\hline \multirow{2}{*}{ Variable } & \multicolumn{2}{l|l|}{ MG estimator } & \multicolumn{2}{l|}{ CCEMG estimator } \\
\cline { 2 - 5 } & Coefficient & p-value & Coefficient & p-value \\
\hline $\ln$ (personnel in the R\&D sector) & 0.094 & 0.057 & -0.080 & 0.022 \\
\hline $\ln ($ capital formation) & 0.140 & 0.000 & 0.140 & 0.000 \\
\hline $\ln ($ EDI $)$ & 0.779 & 0.017 & 0.883 & 0.013 \\
\hline Cross-section averaged $\ln (\mathrm{GCI})$ & - & - & 1.090 & 0.000 \\
\hline $\begin{array}{l}\text { Cross-section averaged } \ln (\text { personnel in the } \\
\text { R\&D sector) }\end{array}$ & - & - & -0.659 & 0.090 \\
\hline $\begin{array}{l}\text { Cross-section averaged } \ln (\text { capital } \\
\text { formation) }\end{array}$ & - & - & -0.111 & 0.003 \\
\hline Cross-section averaged $\ln (\mathrm{EDI})$ & 0.199 & 0.060 & -0.606 & 0.093 \\
\hline Constant & 2.222 & 0.726 & 0.712 & 0.350 \\
\hline
\end{tabular}

According to Table 3, the GCI changes are explained by changes in EDI, R\&D personnel, and capital formation. Capital formation and EDI have a positive contribution to GCI. In this case, $\mathrm{R} \& \mathrm{D}$ personnel seems irrelevant for competitiveness. The unequal access to education determines decrease in GDP per capita in many countries. The results contradict the results of the emerald model used by Akpinar et al. (2015), who highlight that education and R\&D are the third and fourth most influential factors of competitiveness in the EU. The results for EU countries are in line with Fathy \& Safijllin (2019), who showed that innovation is not enough to support significant economic development.

Authors checked for cointegration between the natural logarithm of GDP per capita/logarithm of GCI and the regressors in the model with ME estimators: natural logarithm of expenditure in the R\&D sector, FDI stock, capital formation, and labor force. According to the Westerlund test, all the panels are cointegrated at a 10\% level of significance. This result confirms a long-run relationship between these variables. 
Granger causalities were checked using stationary panel data using GDP per capita, variation in expenditure per capita in the R\&D sector, FDI stock, capital formation, and labor force. According to the results of Hurlin \& Dumitrescu (2012), a Granger causality test indicated a bidirectional causal relationship between GDP per capita and capital formation (computed statistics: 9.1335 and 7.9433, p-values $<0.05$ ) as well as a causal relationship between FDI stock and GDP per capita for the EU-28 countries in the period 2004-2018 (calculated stat. $=2.7594$, p-value=0.0058). Using a Cobb Douglas model, Kosztowniak (2013) also found that the employment relationship with GDP is insignificant and negative. Rusu \& Roman (2018) explain this finding by the fact that the great number of jobs were chosen instead of hours of work. The volume of FDI inflows depends on labor force capacity to apply the new technology and to value it. Previous studies highlight the finding that effects come under theoretical expectations because of the absence of adaptability of the labor force to the new technologies. Bronzini \& Piselli (2009) consider that R\&D activity could have a slowing effect in reducing the disparities between countries. Hall et al. (2010) show that private R\&D funds have a positive impact on GDP growth compared to government R\&D funds.

The construction preliminary tests of the prior models were applied to all the regression models. Issues like endogeneity, heteroskedasticity, and autocorrelation were particularly examined before estimator selection. The Wooldridge test for autocorrelation was based on Drukker's method, likelihood ratio tests for investigating heteroskedasticity was applied, with the results confirming the presence of heteroskedasticity and autocorrelation. Variance Inflation Factors (VIF) were computed for each explanatory variable to check for multicollinearity, but the values of VIF did not indicate a multicollinearity issue. While heteroskedasticity and autocorrelation were existent, endogeneity was found to be an issue. Therefore, authors used the GMM system for estimating the models in Tables 4 and 5.

Tab. 4 - Determinants of GDP per capita in the EU (2004-2018) (System GMM estimation). Source: own research

\begin{tabular}{|l|l|l|l|}
\hline Variable & Coefficient & t-statistics & p-value \\
\hline GDP per capita in the previous year & 0.405 & 10.29 & 0.000 \\
\hline Variation in expenditure in the R\&D sector & -0.012 & -7.21 & 0.000 \\
\hline FDI stock & 0.000005 & 2.49 & 0.013 \\
\hline Capital formation & 0.105 & 1.74 & 0.083 \\
\hline Constant & 3.154 & 1.8 & 0.073 \\
\hline
\end{tabular}

The panel data model in Table 4 indicates that FDI stock has a low positive impact on GDP per capita. In contrast, capital formation has the most substantial positive impact, as expected. Variation in expenditure in the R\&D sector is negatively and weakly correlated to GDP per capita. Other authors consider that the R\&D influence on economic growth is not automatically positive since R\&D utilization depends on many institutional and social factors as well as country specificity (Simionescu et al., 2017). More expenses in the R\&D sector are not reflected in the improvement of living standards, as time is necessary to incorporate the results of this sector 
into the real life of the population. The $\mathrm{R} \& \mathrm{D}$ policies were better correlated with the global competitiveness index (see Table 5).

Tab. 5 - Determinants of GCI variation in the EU (2004-2018) (System GMM estimation).

Source: own research

\begin{tabular}{|l|l|l|l|}
\hline Variable & Coefficient & t-statistics & $\mathrm{p}$-value \\
\hline GCI variation in the previous year & 0.225 & 3.27 & 0.001 \\
\hline Capital formation & 0.012 & 6.02 & 0.000 \\
\hline Variation in the personnel in the R\&D sector & 0.000002 & 5.68 & 0.000 \\
\hline Constant & 3.159 & 10.02 & 0.000 \\
\hline
\end{tabular}

The panel data model in Table 5 indicates that variation in GCI in the EU is explained by the capital formation and variation in the personnel engaged in R\&D activities. As for the panel data models in Table 4 and Table 5 based on system GMM, the results of the Sargan test indicate that the null hypothesis of the exogenous instruments was not rejected. The Arellano-Bond test for idiosyncratic error autocorrelation suggests no autocorrelation. The test results for AR (1) and AR (2) processes in terms of first differences rejects the null assumption. According to the latest data published in 2019, only two EU countries placed in the period 2017-2018 among the 10 most competitive countries in the world according to GCI values: the Netherlands (rank 4) and Germany (rank 7). In this context, a separate analysis of those countries would be necessary to identify the main drivers of competitiveness in each case.

In Table 6, the factors are presented that influence GCI in the Netherlands based on the Ridge regression with marginal MLE standardized coefficients (posterior mean) and the posterior probability that the standardized coefficient is within 1 standard deviation of 0 (prob.).

Tab. 6 - Ridge regressions with marginal MLE to explain GCI in the Netherlands and Germany (2004-2018). Source: own research

\begin{tabular}{|l|l|l|l|l|}
\hline Covariate & Netherlands & \multicolumn{2}{l|}{ Germany } \\
\hline & posterior mean & prob. & $\begin{array}{l}\text { posterior } \\
\text { mean }\end{array}$ & prob. \\
\hline intercept & 0 & 1 & 0 & 1 \\
\hline $\ln ($ expenditure in R\&D) & 0.006 & 0.514 & 0.006 & 0.480 \\
\hline $\ln ($ EDI $)$ & 0.007 & 0.661 & 0.004 & 0.557 \\
\hline $\ln ($ personnel in R\&D) & 0.007 & 0.458 & 0.007 & 0.439 \\
\hline $\ln$ (innovation index) & 0.006 & 0.427 & 0.003 & 0.566 \\
\hline $\ln ($ capital formation) & 0.005 & 0.509 & 0.008 & 0.243 \\
\hline $\ln ($ FDI stock) & 0.007 & 0.605 & 0.002 & 0.642 \\
\hline $\begin{array}{l}\ln (\text { population with tertiary } \\
\text { education) }\end{array}$ & 0.003 & 0.636 & -0.001 & 0.665 \\
\hline $\ln ($ labor force) & & & & \\
\hline & -0.002 & 0.624 & -0.002 & 0.637 \\
\hline
\end{tabular}


According to the ridge regression model in Table 6, the Netherlands' GCI in 2004-2018 depended on the innovation index, personnel in the R\&D sector as well as expenditure in $R \& D$ and FDI stock. The GCI in Germany in the period 2004-2018 depended on capital formation (positive correlation), expenditure in the $\mathrm{R} \& \mathrm{D}$ sector, and personnel in the R\&D sector. These results for Germany suggest that besides capital formation, the performance of the R\&D sector and the inputs in this sector contributed to competitiveness in Germany. However, innovation did not have a significant impact on competitiveness growth in this country. The results for the Netherlands suggest that innovation and human capital in the R\&D sector were the main drivers of competitiveness. Compared to Germany, in the Netherlands, innovation succeeded in transferring the results to economic performance. Analyzing the drive factors of a leader of competitiveness in the world based on WEF and IMD methodology, Loo (2012) show that for many of them innovation (Sweden, Switzerland, US), higher education and training (Switzerland, Sweden, Denmark) and labor market efficiency (US, Denmark) are the most important.

\section{CONCLUSION}

The complexity and dynamics of the competitiveness process in the modern international context have been demonstrated by a multitude of approaches and indicators measuring this process (simple indicators like GDP per capita and composite indicators like GCI, WCI, CGSI). Gaps in economic development among countries influence the impact of the key factors regarding competitiveness. The selection of the variables expressing the key factors is also important in establishing the dimension and the sense of influence.

Human capital plays a crucial role in economic development due to the skills of innovative individuals which improve productivity. Moreover, human capital may determine the adoption of external technology by absorbing new equipment and ideas. Capital formation also has a positive contribution to economic growth. The methodological framework of the Cobb-Douglas function was extended by including, besides labor force and capital formation, aspects related to technological progress, R\&D, and FDI.

The empirical evidence suggests that GDP per capita changes can be explained by alterations in the labor force and capital formation as in the traditional framework of the Cobb-Douglas function, although R\&D expenditure and FDI stock also play a significant role.

The key limitation of the research is related to the GCI, which is a composite indicator; twothirds of the data used for calculating the GCI scores come from survey data, with only a third from statistical data. The utilization of the indicators such as stock and flow variables influences competitiveness analysis results. A limit of the study is given by the heterogeneity of the analyzed countries, which affecst the factors determining competitiveness, as this case study indicates. Rusu \& Roman (2018) demonstrated significant differences among the indicators that determine competitiveness in the EU-10 countries according to the degree of economic development.

\section{Acknowledgment:}

This work is supported by the Scientific Grant Agency of the Ministry of Education, Science, Research, and Sport of the Slovak Republic and the Slovak Academy Sciences as a part of the research project VEGA 1/0797/20: "Quantification of Environmental Burden Impacts of the Slovak Regions on Health, Social and Economic System of the Slovak Republic". 


\section{References}

1. Akpinar, M., Can, Ö., \& Mermercioglu, M. (2015). Determinants of Competitiveness in European Regions: A Test of the Emerald Model. International Journal of Transitions and Innovation Systems, 4(3/4), 114-130. https://dx.doi.org/ 10.1504/IJTIS.2015.077187

2. Altomonte, C., \& Békés, G. (2014). Measuring Competitiveness in a Granular and Global World. Measuring Competitiveness in Europe: Resource Allocation, Granularity and Trade., Brussels: Bruegel Blueprint Series.

3. Baltgailis, J. (2019). The issues of increasing the effectiveness of teaching comparative economics. Insights into Regional Development, 1(3), 190-199. https://dx.doi.org /10.9770 / ird.2019.1.3(1)hal-02188839

4. Bronzini, R., \& Piselli, P. (2009). Determinants of Long-run Regional Productivity with Geographical Spillovers: The role of R\&D, Human Capital and Public Infrastructure. Regional Science and Urban Economics, 39(2), 187-199.

5. Christodoulopoulou, S., \& Tkacevs, O. (2014). Measuring the Effectiveness of Cost and Price Competitiveness in External Rebalancing of Euro Area Countries: What do Alternative HCIs tell us? ECB Working Paper 1736, European Central Bank, 1-34.

6. Diebolt, C., \& Hippe, R. (2019). The Long-run Impact of Human Capital on Innovation and Economic Development in the Regions of Europe. Applied Economics, 51(5), 542-563.

7. Dobrovic, J., Gallo, P., Mihalcova, B., Stofova, L., \& Szaryszova, P. (2018). Competitiveness Measurement in Terms of the Europe 2020 Strategy. Journal of Competitiveness, 10(4), 21-37, https://dx. doi.org/10.7441/joc.2018.04.02

8. Dumančić, R. L., \& Mačkić, V. (2017). What Drives Competitiveness: The Case of New EU Member States. 5th RSEP Social Sciences Conference, 7(10), 161-175.

9. Faggian, A., Partridge, M., \& Malecki, E. (2016). Creating an environment for economic growth: creativity, entrepreneurship or human capital? https://mpra.ub.uni-muenchen. de/71445/1/MPRA_paper_71445.pdf.

10. Fathy, E. Y., \& Safijllin, L. N. (2019). Causal Relationship between Human Capital and Economic Growth in European Countries (EU-28): Panel Analysis. International Journal on Emerging Technologies, 10(2), 66-70.

11. Fernando, I. N. (2020). Tourism Competitiveness by Shift-Share Analysis to way-forward Destination Maninnoagement: A case study for Sri Lanka. Journal of Tourism and Services, 21(11), 88-102. https://doi.org/10.29036/jots.v11i21.139

12. Gavurova, B., Ivankova, V., Rigelsky, M., \& Přívarová, M. (2020). Relations Between Tourism Spending and Global Competitiveness - an Empirical Study in Developed OECD Countries. Journal of Tourism and Services, 21(11), 38-54. https://doi.org/10.29036/jots.v11i21.175

13. Giménez, G., López-Pueyo, C., \& Sanaú, J. (2015). Human Capital Measurement in OECD Countries and its Relation to GDP Growth and Innovation. Revista de Economia Mundial, 39, $77-107$.

14. Hall, B. H., Mairesse, J., \& Mohnen, P. (2010). Measuring the Returns to R\&D. Handbook of the Economics of Innovation, 2, 1033-1082. 
15. Hurlin, C., \& Dumitrescu, E. (2012). Testing for Granger Non-causality in Heterogeneous Panels. Economic Modelling, 29 (4), 1450-1460.

16. Ivanová, E., \& Masárová, J. (2018). Performance evaluation of the Visegrad Group countries. Economic Research-Ekonomska Istraživanja, 31(1), 270-289. https://doi.org/10.1080/133167 7X.2018.1429944

17. Kacprzyk, A., \& Doryń, W. (2017). Innovation and Economic Growth in Old and New Member States of the European Union. Economic Research-Ekonomska Istraživanja, 30(1), $1724-1742$.

18. Kordalska, A., \& Olczyc, M. (2016). Global Competitiveness and Economic Growth: A OneWay or Two-Way Relationship? Equilibrium. Quarterly Journal of Economics and Economic Policy, 11(1), 121-142. http://dx.doi.org/10.12775/EQUIL.2016.006

19. Kosztowniak, A. (2013). Foreign Direct Investment as a Factor of Economic Growth in Poland. Empirical Analysis for the Period 1995-2012. Advances in Economics and Business, 1(2), 203-212. https://doi.org/10.13189/aeb.2013.010215

20. Landesmann, M., Leitner, S., \& Stehrer, R. (2015). Competitiveness of the European economy (No. 2015/01). EIB Working Papers.

21. Loo, M. K. L. (2012). Competitiveness: top five nations last decade and next decade. International Journal of Business and Management Studies, 1(3), 391-412.

22. Marčeta, M., \& Bojnec, Š. (2020). Drivers of Global Competitiveness in the European Union Countries in 2014 and 2017. Organizacija, 53(1), 37-52, http://dx.doi.org/10.2478/orga-20200003

23. Manuylenko, V. V., Mishchenko, A. A., Bigday, O. B., Putrenok, Y. L., \& Savtsova, A. V. (2015). A Comprehensive Definition of the Concept of Innovation in Russian and International Science. International Journal of Economics and Financial Issues, 5(4),1029-1037.

24. Mura, L., (2020). Innovation and Marketing Management of Family Businesses: Results of Empirical Study. International Journal of Entrepreneurial Knowledge, 8(2), 56-66. https://doi. org/10.37335/ijek.v8i2.118

25. Nekrep, A., Strašek, S., \& Boršič, D. (2018). Productivity and Economic Growth in the European Union: Impact of Investment in Research and Development. Naše gospodarstvo/Our Economy, 64(1), 18-27. http://dx.doi.org/ 10.2478/ngoe-2018-0003

26. Olczyk, M. (2016). International Competitiveness in the Economics Literature: A Bibliometric Study. Athens Journal of Business \& Economics, 2(4), 375-388.

27. Pesaran, M. H. (2006). Estimation and inference in large heterogeneous panels with a multifactor error structure. Econometrica, 74(4), 967-1012.

28. Pesaran, M. H., \& Smith, R. (1995). Estimating long-run relationships from dynamic heterogeneous panels. Journal of econometrics, 68(1), 79-113.

29. Pesaran, M. H., Shin, Y., \& Smith, R. P. (1999). Pooled mean group estimation of dynamic heterogeneous panels. Journal of the American Statistical Association, 94 (446), 621-634.

30. Pesaran, M. H. (2006). Estimation and inference in large heterogeneous panels with a multifactor error structure. Econometrica, 74(4), 967-1012. 
31. Petrariu, I. R., \& Bumbac, R., \& Ciobanu, R. (2013). Innovation: a Path to Competitiveness and Economic Growth. The case of CEE countries. Theoretical and Applied Economics, 5(582), $15-26$

32. Priede, J., \& Pereira, E. T. (2013). Innovation as a Key Factor in the International Competitiveness of the European Union. European Integration Studies, 7, 212-221. http://dx.doi. org/10.5755/j01.eis.0.7.4228

33. Pried, J., \& Pereira, E. T. (2015). European Union's Competitiveness and Export Performance in Context of EU - Russia Political and Economic Sanctions, 11th International Strategic Management Conference 2015. Procedia - Social and Behavioural Sciences, 207, 680-689.

34. Priede, J., \& Neuert, J. (2015). Competitiveness Gap of the European Union Member Countries in the Context of Europe 2020 Strategy, 11th International Strategic Management Conference 2015. Procedia - Social and Behavioural Sciences, 207, 690-699.

35. Př́vara, A. (2020). Labour market efficiency and emigration in Slovakia and EU neighbouring countries. Economic Research-Ekonomska Istraživanja, http://dx.doi.org/10.1080/133167 7X.2020.1858131

36. Rusu, V. D., \& Roman A. (2018). An empirical analysis of factors affecting competitiveness of C.E.E. countries. Economic Research-Ekonomska Istraživanja, 31(1), 2044-2059. http://dx.doi. org./ 10.1080/1331677X.2018.1480969

37. Schwab, K. (2019). The Global Competitiveness Report 2019, World Economic Forum. http://www3.weforum.org/docs/WEF_TheGlobalCompetitivenessReport2019.pdf

38. Schwab, K., \& Zahidi, S. Global competitiveness report: special edition 2020. World Economic Forum.

39. Simionescu, M., Lazány, K., Sopková, G., Dobeš., K., \& Balcerzak, A. P. (2017). Determinants of Economic Growth in V4 Countries and Romania. Journal of Competitiveness, 9(1), 103-116. https://doi.org/10.7441/joc.2017.01.07

40. Squalli, J., Wilson, K., \& Hugo, S. (2008). An analysis of growth competitiveness. International Review of Applied Economics, 22(1), 105-126.

41. Suroso, A., Rafinda, A., \& Gal, T. (2020). The evaluation of entrepreneur incubation program at higher education. International Journal of Entrepreneurial Knowledge, 8(2), 14-26. https://doi. org/10.37335/ijek.v8i2.113

42. Szeles, M. R., \& Simionescu, M. (2020). Regional Patterns and Drivers of the EU Digital Economy. Social Indicators Research, 1-25.

43. Westerlund, J., \& Edgerton, D. L. (2007). A panel bootstrap cointegration test. Economics letters, 97(3), 185-190. https://doi.org/10.1016/j.econlet.2007.03.003

44. Wolff, G. B. (2016). Foreword in Measuring competitiveness in Europe: resource allocation, granularity and trade. Bruegel Blueprint Series, (19). https://ec.europa.eu/docsroom/ documents/28181

45. Zoroja, J., \& Pejić Bach, M. (2016). Impact of Information and Communication Technology to the Competitiveness of European Countries - Cluster Analysis Approach. Journal of Theoretical and Applied Electronic Commerce Research, 11(1), 1-10. https://doi.org/10.4067/S071818762016000100001 


\section{Contact information}

prof. Mibaela Simionescu, Ph.D.

Romanian Academy

Institute for Economic Forecasting

Romania

E-mail:mihaela.simionescu@ipe.ro

ORCID: bttps://orcid.org/0000-0002-6124-2172

prof. Elena Pelinescu, Ph.D.

Romanian Academy

Institute for Economic Forecasting

Romania

E-mail:epel@ipe.ro

ORCID: https://orcid.org/0000-0001-9267-2768

assoc. prof. Samer Khouri, Ph.D.

Technical University of Kosice

Faculty of Mining, Ecology, Process Control and Geotechnology

Slovakia

E-mail:samer.khouri@tuke.sk.

ORCID: https://orcid.org/0000-0001-7243-5124

Svitlana Bilan, Ph.D.

Technical University of Košice

Faculty of Mining, Ecology, Process Control and Geotechnology

Poland

E-mail:s.bilan@prz:edu.pl

ORCID: https://orcid.org/0000-0001-9814-5459 